\title{
Erratum to: Children and Life Satisfaction
}

\author{
Luis Angeles
}

Published online: 12 March 2010

(C) Springer Science+Business Media B.V. 2010

\section{Erratum to: J Happiness Stud DOI 10.1007/s10902-009-9168-z}

After publication of the paper "Children and Life Satisfaction" I have uncovered an important coding mistake in the dataset. Several observations of the life satisfaction measure were unintentionally assigned the wrong value in the construction of the panel.

After correcting the problem, the main results of the paper no longer hold. The effect of children on the life satisfaction of married individuals is small, often negative, and never statistically significant. I ask all readers to disregard the results of this paper and deeply apologize for this unfortunate mistake. I have asked the journal to withdraw the paper but, being too late for that, an erratum was the only alternative.

The online version of the original article can be found under doi:10.1007/s10902-009-9168-z.

L. Angeles $(\bowtie)$

Department of Economics, University of Glasgow, Adam Smith Building, Glasgow G12 8RT, UK

e-mail: 1.angeles@lbss.gla.ac.uk 